\title{
Information and Communication Technology Sustainability Management of Bangladesh
}

\author{
Hasan Boktiar ${ }^{1}$, Rubaiat Jahan ${ }^{2}$ \\ ${ }^{1}$ Department of ICT \& GIS, Institute of Water Modelling, Dhaka, Bangladesh \\ ${ }^{2}$ Department of Sociology, University of Dhaka, Dhaka, Bangladesh \\ Email address: \\ hasanboktiar@gmail.com (H. Boktiar), rubaiatjahandu@gmail.com (R. Jahan)
}

\section{To cite this article:}

Hasan Boktiar, Rubaiat Jahan. Information and Communication Technology Sustainability Management of Bangladesh. International Journal of Sustainability Management and Information Technologies. Vol. 3, No. 5, 2017, pp. 53-56. doi: 10.11648/j.ijsmit.20170305.12

Received: September 21, 2017; Accepted: November 21, 2017; Published: December 14, 2017

\begin{abstract}
We are often to told that we are living in an "Information Age" and indeed, this is a truth that seems self-evident: communications and information technologies pervade our home, our workplaces, governance, our educations. The government of Bangladesh declare vision 2021 for sustainable management of information and communication technology.
\end{abstract}

Keywords: Bangladesh, Governance, Vision, BNEA, e-GP, BCC, CIRT

\section{Introduction}

Bangladesh is going to celebrate the golden jubilee of the nation in the year 2021. The 'Vision 2021' aims at developing Bangladesh into a resourceful and modern economy through efficient use of information and communication technology. This goal has eloquently been described by the Prime Minister as 'Digital Bangladesh'. It is believed that through the successful implementation of the ICT policy and its principles it would be possible to create a Digital Bangladesh by 2021 as promised by the government.

With the onset of globalization, the international environment for trade, business and investment, has become far more competitive than any time in the past and there is no option but for Bangladesh to be transformed into a knowledgedriven economy to survive in this fierce competition. Natural physical endowment and history will play a limited role; human ingenuity, ideas and skill will play the principal role in the creation of future wealth. Information and communication technologies (ICT) have greatly reduced the cost and increased the capacity of organizations to codify knowledge, process and communicate information. The national ICT Policy 2009 has expressed its vision which will assist Bangladesh to move towards a poverty free middle income prosperous country by 2021. Its vision includes plans to expand the information and communication technology, and then take advantage of this to establish a transparent, committed and accountable government, develop skilled manpower, improve social justice and manage public services.

\section{Bangladesh National Enterprise Architecture}

\subsection{Background of BNEA}

The Bangladesh Computer Council (BCC) is one of the apex bodies of the GoB that has been instrumental in carving the path for the development of e-Governance in Bangladesh over the last two decades. At present, the BCC is in the process of determining the potential success of e-Governance in Bangladesh through the establishment of the 'National Enterprise Architecture and Interoperability Framework' initiative. This initiative shall be the foundation for the successful ICT adoption in the Government [7].

The template is used to format your paper and style the text. All margins, column widths, line spaces, and text fonts are prescribed; please do not alter them. You may note peculiarities. For example, the head margin in this template measures proportionately more than is customary. This measurement and others are deliberate, using specifications that anticipate your paper as one part of the entire proceedings, and not as an independent document. Please do not revise any of the current designations. 


\subsection{Standard of BNEA}

1) Application architecture Standards

2) Business architecture Standards

3) Data architecture Standards

4) E-GIF Standards

5) Mobile Service Delivery Platform Standards

6) Security Standards

7) Technology architecture Standards

\subsection{E-Service of $\mathrm{BNEA}$}

E-Services are a critical component for establishing eGovernment. All government entities under the Digital Bangladesh vision are currently engaged in provided electronic services or e-services to the citizens and business. E-Services are the final outcome from BNEA (Bangladesh national Enterprise Architecture). The BNEA framework, principles, standards, guidelines, software, tools and infrastructure would be used to develop better, improved, accessible and reusable e-Services by government organizations. E-Services would include government-togovernment (G2G) or government-to-citizen (G2C) or government-to-business (G2B) or government-to-employee (G2E).

The Government under BNEA has introduced National Enterprise Architecture (NEA) Bus (known as National eService Bus) under Bangladesh National Enterprise Architecture (BNEA) framework to ensure interoperability, availability and reusability of government online services, information and data. National e-Service Bus is software driven middleware platform which is being developed keeping a provision to enable online services, sharing of information and data of ministries, departments and directorates to ensure interoperability and end user's easy access to it.

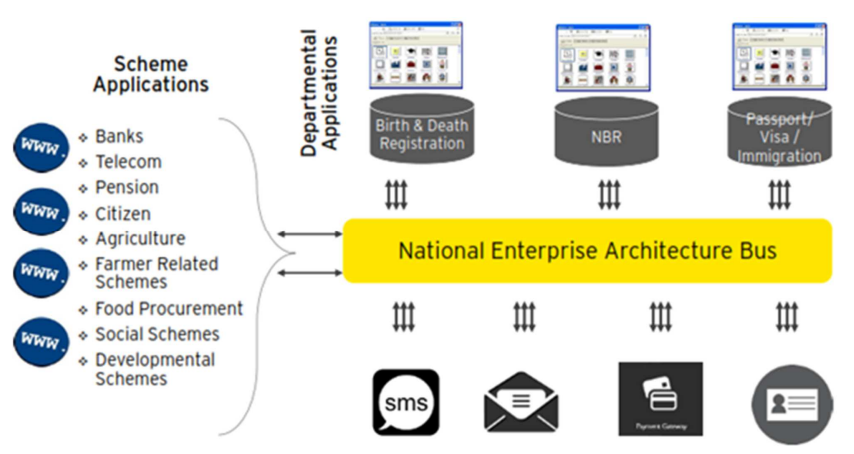

Figure 1. Bangladesh National Enterprise Architecture (BNEA) framework

NEA bus is a critical component in the interoperability architecture domain and key to ensuring seamless exchange of information and services for Government of Bangladesh. Considering the scope and span of NEA bus, due procedures and guidelines have been established around the governance to ensure robust and standardized controls are being followed by the NEA working team. NEA bus is based on service oriented architecture paradigm. The service definition and deployment lifecycle has been covered and due procedures including the roles and responsibilities defined for the benefit of the SOA team working on NEA bus. As a part of BNEA phase 1 conceptualization, couple of e-services have been developed on the BNEA components (NEA bus, service delivery platform and national data center cloud). The individual software components comprising of these eservices would be made available to other government organizations to enable faster software development time and reduce development costs. E-services that are already integrated with e-service bus:

1) e-Pension for Directorate of Primary and Mass Education

2) Food procurement system for DG Food office

3) Online Recruitment System for ICT Division

4) NID verification service

5) Govt. Employee verification service

6) Alapon Messenger App

7) Geospatial Data service

More applications and services are in pipeline to be integrated with national e-service bus shortly. Each of these three e-Services share common platforms and technologies:

1) BNEA design and standards have been used to build the foundation architecture for the three E-services

2) All of the e-services are registered on the NEA Bus

3) The three e-Services uses common technology and programming languages

4) They are using the same business automation and workflow engine

5) Common reporting engine has been used to meet the backend reporting requirements

6) They are hosted on shared cloud infrastructure (BCC national data center

For example, citizen authentication is a foundation building block used by all these three e-Services. A citizen is required to be authenticated against NID database for job application, a farmer needs to be authenticated to be eligible for selling grains to government and teachers are required to establish their identity through national identity. Hence all the three e-services require authentication of a citizen against the NID database.

\subsection{Prepare National Data Center}

A data center (or datacenter) is a facility used to house computer systems and associated components, such as telecommunications and storage systems. It generally includes redundant or backup power supplies, redundant data communications connections, environmental controls (e.g., air conditioning, fire suppression) and security devices.

The National Data Center is built based as per international standards. All necessary mission architecture have fully redundant package providing maximum robustness to the architecture. The system is flexible to cater any plug-in as and when required in terms of adding additional network architecture. The National Data Center meets international Data Center design standards TIA 942 \& UPTIME INSTITUTE's TIER III, Data Center will be certified TIER 3 from accredited certifying organization EPI India. As a Tier 
III certified Data Center the center has multiple active power and cooling distribution paths, but only one path active, has redundant components, and is concurrently maintainable, providing $99.982 \%$ availability.

(1) Hosted services for web, application using Data Center's facility and

(2) Services for installing client equipment's in the Data Center for client's internet services, backup, storage etc.

\section{3. eGovernment Master Plan}

Formation of the e-Government Master Plan for Digital Bangladesh:

Contribute to materializing Bangladesh government's Digital Bangladesh by 2021' vision through establishing the e-Government Master Plan; Enhance the capacity building of Bangladeshi government officials for 'Digital Government' through sharing the experience and know-how of Korea's eGovernment development; Implement a pilot project for the purpose of catalyzing the realization of Bangladesh's eGovernment Master Plan; ICT Roadmap preparation for 52 Ministries \& Divisions, 68 Departments and organizations under the Bangladesh National Enterprise Architecture Framework (BNEAF).

\section{Leveraging ICT}

Leveraging ICT for Growth, Employment and Governance is a project of Bangladesh Computer Council (BCC) under the Ministry of Information and Communication Technology. The project has been launched in January 2013 aiming to develop a vibrant and healthy Information Technology (IT) and Information Technology-Enabled Services industry in five years by identifying the strategies, programs and investment needed for the country to leverage ICT for economic growth and competitiveness [14].

The primary objectives of the project are to catalyze the growth of Bangladesh's IT/ITES industry for employment creation and export diversification. The project will also cater the need of public sector modernization through development of policies, guidelines, e-government interoperability framework (eGIF) and capacity development of the government people.

Some specific objectives of the projects are:

1. To develop 34,000 skilled manpower for IT and ITES sector.

2. To expose local IT and ITES capabilities in to global market leading to improved global awareness and perception of Bangladesh for IT and ITES business.

3. To make available shared IT hosting and remote conferencing facilities for use by GOB agencies to policies, fix appropriate standards and guidelines for enterprise architecture and information security.

$\mathrm{BCC}$ is the implementing agency of the project worth about Taka 572.48 crore. Of the total amount, the World Bank is providing $\$ 70$ million US dollars and the rest by the Government of Bangladesh. The project is expected to be completed by 2018 .

\section{Info-Sarker Project}

To expand the government wide network to be established under Phase-I BanglaGovNet Project to all the District and Upazilla level offices throughout the country. To improve government efficiency and promote interaction between ministries/divisions, departments, districts and upazillas by construction of government ICT network infrastructure. To use ICT system within the public administration to improve efficiency, accountability and transparency, reduce wastage of resources, enhance planning and raise the quality of services. To maximize the automation of work processes through integrated information management system utilizing National E-Service System (NESS).

Project background:

The Government of Bangladesh is actively adopting Egovernance. E-governance would:

1. Increase the quality of public services.

2. Improve decision-making processes and Promote transparency and accountability in the business process of governance.

However, to successfully deliver e-services, the following are required:

Connectivity between all government agencies.

A centralized data management system, which can support data processing, sharing and coordination.

Adequate security features to protect the integrity of government data from various vulnerabilities.

Info-sarker project is the second phase of an effort to meet the above requirement. Bangla-GovNet project being implemented by BCC builds the ICT Backbone Network up to the district headquarters. Info-Sarker extends this network up to the upazilla level, connects the government offices at district and upazilla level. Its scope also includes expansion of National Data Center, establishing Disaster Recovery Center, WI-Fi Network, distribution of Tablet PCs etc.

Without the proper implementation of this project efforts to render E-services at the door-steps of our people would be difficult - if not impossible.

Project Scope:

The Government IP network

Expand Connectivity:

(1) Connect all government offices at the district level (on an average 55 offices for each District).

(2) Connect all government offices at the upazilla level (on an average 30 offices for each Upazilla).

(3) Backbone Connectivity from 64 Districts to 421 Upazillas (except those 64 Upazillas which have already been covered in Bangla GovNet project).

\section{BGD e-GOV CIRT}

BGD e-GOV CIRT mission is to support government efforts to develop and amplify ICT programs by establishing incident management capabilities within Bangladesh, which 
will make these programs more efficient and reliable [11]

MAIN OBJECTIVES OF THE BGD E-GOV CIRT ARE:

1) Manage cyber security in Bangladesh government's eGovernment network and related infrastructure;

2) Serve as a catalyst in organizing national cyber security resilience initiatives (education, workforce competence, regulation, cyber exercises) among various stakeholders;

3) Make efforts to establish national cyber security incident management capabilities in Bangladesh [7].

TO ACHIEVE THIS GOAL, BGD E-GOV CIRT DURING THE FIRST STAGE OF ITS DEVELOPMENT WILL:

1) Monitor the network for the events that affect security of the government network;

2) Carry out investigations and containment measures for cyber security events in order to minimize data loss or service disruption in the government network and eservices;

3) Help to solve security related issues in National Data Center (NDC) including provision of obligatory instructions for $\mathrm{BCC}$ personnel to secure NDC information resources;

4) Carry out preventive measures in order to minimize disruptions of secure operations of the government network and e-services;

5) Participate in international and national cyber security initiatives;

6) Promote and strengthen cyber security environment by developing, collaborating and maintaining relationships with other CIRTs and organizations in the country and abroad;

7) Support capacity building of the existing manpower of BCC to establish national CIRT.

\section{7. e-Government Procurement (e-GP) System}

National e-Government Procurement (e-GP) portal (i.e. https://www.eprocure.gov.bd) of the Government of the People's Republic of Bangladesh is developed, owned and being operated by the Central Procurement Technical Unit (CPTU), IME Division of Ministry of Planning. The e-GP system provides an on-line platform to carry out the procurement activities by the Public Agencies - Procuring Agencies (PAs) and Procuring Entities (PEs) [13].

The e-GP system is a single web portal from where and through which PAs and PEs will be able to perform their procurement related activities using a dedicated secured web based dashboard. The e-GP system is hosted in e-GP Data Center at CPTU, and the e-GP web portal is accessible by the PAs and PEs through internet for their use.

This complete e-GP solution introduced under the Public Procurement Reform (PPR) Program is being supported by the World Bank and gradually used by all government organizations. This online platform also helps them ensuring equal access to the Bidders/Tenderers and also ensuring efficiency, transparency and accountability in the public procurement process in Bangladesh.

\section{References}

[1] https://www.ictd.gov.bd

[2] http://www.bcc.gov.bd/

[3] http://doict.gov.bd/

[4] http://cpd.org.bd/bangladesh-vision-2021

[5] http://bangladesh.gov.bd

[6] http://nea.bcc.gov.bd

[7] http://bcc.portal.gov.bd

[8] http://bcc.portal.gov.bd/sites/default/files/files/bcc.portal.gov.b $\mathrm{d} /$ page/fb4084a3 f7f4 43df a2bd 02a570f9c94d/UserPolicyfo rNDC.pdf

[9] http://bangladesh.gov.bd/sites/default/files/files/bangladesh.gov .bd/page/6dca6a2a_9857_4656_bce6_139584b7f160/Perspecti ve-Plan-of-Bangladesh.p̄̄f

[10] http://www.bcc.gov.bd/site/page/575bced6-413c-4b56-ab47$35 \mathrm{c} 56 \mathrm{~d} 2454 \mathrm{f} 2$

[11] https://www.cirt.gov.bd

[12] http://www.thedailystar.net/business/national-data-centre-beready-2017-1302760

[13] https://www.eprocure.gov.bd

[14] www.lict.gov.bd 